\title{
THE EFFECT OF ROLE PLAYING AND SNOWBALL THROWING LEARNING MODEL ON STUDENTS' SPEAKING SKILL AT GRADE III ELEMENTARY SCHOOL IN GUGUS RA KARTINI
}

\author{
Yusmi $^{1}$, Su' $^{6} d^{2}$, Murtono $^{3}$ \\ 1,2,3 Universitas Muria Kudus, Indonesia \\ 1yusmilundo221@gmail.com, ${ }^{2}$ su'ad@umk.ac.id, ${ }^{3}$ murtono@umk.ac.id
}

\begin{abstract}
The purpose of this study was to describe the influence of role playing and snowball throwing learning models on students' speaking skills at third grade elementary school in RA Kartini cluster. This research was an experimental research. The population in this study were students at grade III of elementary schools in RA Kartini cluster. From this population, the research samples were 60 grade III elementary school students. Data collection techniques included giving questionnaires, observation and documentation. The final analysis utilized descriptive analysis and inferential analysis. Inferential analysis was coducted by operating independent sample t-test to determine the influence role playing and snowball throwing models. The results of the analysis of the first hypothesis test between the role playing class and the conventional class showed a significance value of 0,000 (0,000 $<0.05)$ and the $t_{\text {count }}$ value was 3,943, while the $t_{\text {table }}$ value was 2.024 (3,943> 2,024), meaning that $H_{a l}$ was accepted. This indicated that role paying had an effect on speaking skills. The second hypothesis test between the snowball throwing class and the conventional class showed a significance value of $0.02(0.02<0.05)$ and the t-count value of 3.370, while the t-table value was $2.024(3,370>2,024)$ meaning that $H_{a 2}$ was accepted. This confirmed that the snowball model throwing significantly influenced the students' speaking skills. The third hypothesis test showed that between the role playing and snowball throwing learning models the significance value of speaking skills was $0.017(0.017<0.05)$ and the t-count value was 2.498 while the $t$ table value was 2.024 (2.498> 2.024). Referring to the hypothesis testing, Ha was accepted and $H_{o 3}$ was rejected while $H_{a 3}$ was accepted. Thus, it was concluded that role playing learning model was more influential than snowball throwing learning on the students' speaking skills at the second grade of elementary school in Gugus RA Kartini.
\end{abstract}

Keywords: role playing, snowball throwing, speaking skill

\section{PENGARUH MODEL PEMBELAJARAN ROLE PLAYING DAN SNOWBALL TRHOWING TERHADAP KETERAMPILAN BERBICARA SISWA SD KELAS III DI GUGUS RA KARTINI}

\begin{abstract}
Tujuan penelitian ini adalah mendeskripsikan seberapa besar pengaruh model pembelajaran role playing dan snowball throwing terhadap keterampilan berbicara siswa kelas III SD di gugus RA Kartini. Penelitian ini merupakan penelitian eksperimen. Populasi dalam penelitian ini merupakan siswa SD Kelas III yang ada di Gugus RA Kartini. Dari populasi tersebut diambil sample penelitian berjumlah 60 siswa SD kelas III. Teknik pengumpulan data meliputi pemberian angket, observasi dan dokumentasi. Pada Analisis akhir menggunakan analisis deskriptif dan analisis inferensial. Analisis inferensial menggunakan uji independent sample t-test untuk mengetahui seberapa besar pengaruh penggunaan model role playing dan snowball throwing. Hasil analisis uji hipotesis pertama antara kelas role playing dan kelas konvensional menunjukkan nilai signifikansi sebesar $0.000(0.000<0.05)$ dan nilai $t_{\text {hitung }}$ sebesar 3.943, sedangkan nilai $t_{\text {tabel }} 2.024$ yaitu $(3.943>2.024)$, yang artinya $\mathrm{Ha}_{1}$ diterima bahwa role paying berpengaruh terhadap ketrampilan berbicara. Uji hipotesis kedua antara kelas snowball throwing dan kelas konvensional menunjukkan nilai signifikansi sebesar sebesar 0.02 ( $0.02<0.05)$ dan nilai $\mathrm{t}_{\text {hitung }}$ sebesar 3.370, sedangkan nilai $\mathrm{t}_{\text {tabel }} 2.024$ yaitu $(3.370>2.024)$ yang artinya $\mathrm{Ha}_{2}$ diterima bahwa model snowball throwing berpengaruh terhadap ketrampilan berbicara. Dan uji hipotesis yang ketiga menunjukkan antar model pembelajaran role playing dan snowball throwing nilai signifikansi ketrampilan berbicara Bahasa Indonesia sebesar $0.017(0.017<0.05)$ dan nilai $t_{\text {hitung }}$ sebesar 2.498 , sedangkan nilai $\mathrm{t}_{\text {tabel }} 2.024$ yaitu $(2.498$ > 2.024). Mengacu pada ketentuan pengambilan keputusan uji hipotesis, maka Haditerima dan $\mathrm{Ho}_{3}$ ditolak dan $\mathrm{Ha}_{3}$ diterima. Dengan demikian, dapat disimpulkan bahwa model pembelajaran role playing lebih berpengaruh daripada pembelajaran snowball throwing terhadap ketrampilan berbicara siswa SD kelas II di Gugus RA Kartini.
\end{abstract}

ABSTRAK

Kata Kunci: model role playing, snowball throwing, ketrampilan berbicara

\begin{tabular}{|c|c|c|}
\hline Submitted & Accepted & Published \\
\hline 23 September 2020 & 05 September 2021 & 16 September 2021 \\
\hline
\end{tabular}

\begin{tabular}{|l|c|c|c|}
\hline Citation & $:$ & $\begin{array}{r}\text { Yusmi, Y., Su'ad, S., \& Murtono, M. (2021). The Effect of Role Playing and Snowball Throwing Learning Model on } \\
\text { Students' Speaking Skill at Grade III Elementary School in Gugus RA Kartini. Jurnal PAJAR (Pendidikan dan } \\
\text { Pengajaran), 5(5), 1377-1385. DOI : http://dx.doi.org/10.33578/pjr.v5i5.8164. }\end{array}$ \\
\hline
\end{tabular}




\section{PENDAHULUAN}

Perkembangan peserta didik dalam menghadapi tantangan global abad-21 telah digencar-gencarkan oleh pemerintah mulai masa ini. Hal ini dipercaya karena pendidikan mampu memperbaiki kualitas manusia, kompetensi inti yang dikembangkan dalam kurikulum 2013 ini diharapkan dapat mendorong kemampuan siswa mempunyai karakter dan kepribadian. Maka, sangat disarankan kurikulum 2013 menggunakan pendekatan saintifik. Hal ini sama seperti yang Dikemukakan oleh Mulyasa (2013:163) bahwa kurikulum 2013 merupakan kurikulum yang berbasis karakter dan kompetensi. Sependapat dengan Lazim M. (2013:2) bahwa kurikulum 2013 menekankan kompetensi yang seiMbang antara pengetahuan, sikap dan keterampilan melalui pembelajaran yang holistik dengan menggunakan pendekatan saintifik yang di dalamnya terdapat keterampilan mengamati, mengklasifikasi, mengukur, meramalkan, menjelaskan dan menyimpulkan. Atas dasar ini pendidikan harus dilaksanakan seperti dalam kehidupan sehari-hari, sebagaimana yang diharapkan dalam kurikulum 2013.

Model pembelajaran kooperatif memiliki berbagai macam tipe. diantaranya yaitu model pembelajaran role playing dan snowball throwing. Huda (2013:115-116) memaparkan role playing atau bermain peran merupakan sebuah model pembelajaran yang berasal dari dimensi pendidikan individu maupun sosial. Sedangkan model pembelajaran snowball throwing juga sering disebut snowball fight karena merupakan model pembelajaran yang pertama kali diadopsi dari game fisik dimana segumpulan bola salju dilempar dengan maksud memukul orang lain (Huda, 2014b:226).

Siswa sekolah dasar harusnya mampu berkembang dengan baik dan mampu beradaptasi dengan lingkungan dengan cepat. Kemampuan dalam berbahasa (berbicara) lebih sopan. Namun, yang terjadi pada siswa kelas III SD Gugus RA Kartini berbeda dengan hasil yang telah diharapkan. Kemampuan siswa dalam berbahasa dan sikap kepada siswa lain dan guru tidak lebih baik dari tahun-tahun sebelumnya.
Dari observasi yang dilakukan peneliti, proses pembelajaran di dalam kelas memang sudah menerapkan pendekatan saintifik tetapi masih belum maksimal, ditambah lagi tidak ada media pembelajaran yang digunakan oleh guru kelas. Pembelajaran hanya membacakan materi, menjelaskan singkat dan mengerjakan tugas. Hal ini menyebabkan siswa terlihat tidak tertarik dengan pembelajaran yang berlangsung. Peneliti mampu mengatakan tidak menarik karena adanya sikap yang timbul saat pembelajaan, antara lain adanya sikap siswa yang berbicara sendiri dengan temannya sebangku, siswa menghampiri teman lain dan masih terlihat belum paham saat diberikan tugas.

Guna mengetahui keadaan awal siswa peneliti melakukan pemberian angket kepada kelas eksperiemen maupun kelas kontrol. Hal ini dilakukan peneliti untuk mengetahui seberapa jauh pembelajaran yang telah diberikan guru dalam meningkatkan ketrampilan berbicara siswa. Apabila keenam kelas memiliki kesamaan maka peneliti akan memberikan perlakuan kepada kelas tersebut. Dalam hal ini peneliti memberikan angket kepada 30 siswa dimana setiap kelas diambil 5 anak untuk sample.

Dari data yang diperoleh, peneliti tertarik untuk meneliti model pembelajaran yang sederhana untuk meningkatkan keterampilan berbicara siswa dalam menguasai kompetensi yang diajarkan di sekolah. Sehingga judul penelitian ini adalah penerapan model pembelajaran role playing dan snowball throwing terhadap keterampilan berbicara Bahasa Indonesia siswa kelas III SD di Gugus RA Kartini.

\section{KAJIAN TEORETIS}

\section{Model Pembelajaran Role Playing}

Model pembelajaran yang digunakan dalam pembelajaran ini adalah role playing. Menurut Huda (2013:115-116) role playing (bermain peran) merupakan sebuah model pembelajaran yang berasal dari dimensi pendidikan indiIIIidu maupun sosial. Model ini membantu para siswa menemukan makna diri dalam dunia sosial mereka dan membantu 
memecahkan dilema pribadi dengan bantuan kelompok. Dalam dimensi sosial, model ini memudahkan individu untuk bekerjasama dalam menganalisis kondisi sosial,khususnya masalah kemanusiaan. Model ini sangat membantu siswa untuk bersikap sopan dan demokratis dalam menghadapi masalah. Esensi dari model role playing adalah keterlibatan siswa dalam situasi permasalahan dan adanya keinginan untuk memunculkan reIIIolusi yang damai serta memahami apa yang dihasilkan dari keterlibatan langsung itu. Dijelaskan model role- playing adalah model yang intinya tentang keterlibatan langsung pada masalah, diharapkan siswa memahami permasalahan yang dihadapi dan akan timbul respon dari diri siswa untuk memecahkan masalahnya.

Menurut Hamalik (2010:214-217) dalam rangka menyiapakan suatu situasi bermain peran di dalam kelas, guru mengikuti langkah-langlah sebagai berikut.

1) Persiapan dan instruksi

a. Guru memiliki situasi/ dilema bermain drama.

b. Sebelum pelaksanaan bermain peran, siswa harus mengikuti latihan pemanasan, latihan ini diikuti oleh semua siswa, baik sebagai partisBahasa Indonesiasi aktif maupun sebagai para pengamat aktif.

c. Guru memberikan instruksi khusus kepada peserta bermain peran setelah memberikan penjelasan pendahuluan kepada seluruh kelas.

d. Guru memberitahukan peran-peran yang akan dimainkan serta memberikan instruksiinstruksi yang bertalian dengan masingmasing peran kepada para audience.

2) Tindakan dramatik dan diskusi

a. Para aktor terus melakukan perannya sepanjang situasi bermain peran, sedangkan para audience berpartisisi dalam penugasan awal kepada pemeran.

b. Bermain peran harus berhenti pada titik-titik penting atau apabila terdapat tingkah laku tertentu yang menuntut dihentikannya permainan tersebut.

c. Keseluruhan kelas selanjutnya berpartissi dalam diskusi yang terpusat pada situasi bermain peran.
3) Evaluasi bermain peran

a. Siswa memberikan keterangan, baik secara tertulis maupun dalam kegiatan diskusi tentang keberhasilan dan hasil-hasil yang dicapai dalam bermain peran.

b. Guru menilai efektivitas dan keberhasilan bermai peran.

c. Guru membuat bermain peran yang telah dilaksanakan dan telah dinilai tersebut dalam sebuah jurnal sekolah (kalau ada), atau pada buku catatan guru.

\section{Model Pembelajaran Snowball Throwing}

Model pembelajaran snowball throwing merupakan pembelajaran yang dapat dibilang mampu melatih kepercayaan diri siswa. Sedangkan menurut Murtono (2017:86) snowball throwing dapat melatih siswa lebih tanggap menerima pesan dari orang lain. Langkah langkah model pembelajaran snowball throwing dikemukakan oleh Huda (2014:226) adalah sebagai berikut.

1. Guru menyampaikan materi yang akan disajikan

2. Guru membentuk kelompok dan memanggil ketua kelompok untuk memberikan penjelasan tentang materi.

3. Masing-masing ketua kelompok kembali ke kelompok masing-masing kemudian menjelaskan materi yang disampaikan guru.

4. Kemudian masing-masing siswa mengambil satu lembar kerja untuk menuliskan satu pertanyaan apa saja yang menyangkut materi yang dijelaskan ketua kelompok.

5. Kertas yang berisi pertanyaan tersebut dibuat seperti bola dan dilempar kepada teman kelompok lain.

6. Setelah mendapat satu bola dari teman lain, siswa diberi kesempatan untuk menjawab pertanyaan.

7. Guru melakukan evaluasi dan penutup.

\section{Ketrampilan Berbicara}

Salah satu dari keempat keterampilan berbahasa yaitu keterampilan berbicara. Menurut Tarigan (2008:16) berbicara adalah kemampuan mengucapkan bunyi-bunyi artikulasi atau kata-kata untuk mengekspresikan, menyatakan atau 
menyampaikan pikiran, gagasan, dan perasaan. Menurut Nurgiyantoro dalam Mayasari (2014:18) berbicara adalah aktivitas berbahasa kedua yang dilakukanmanusia dalam kehidupan berbahasa, yaitu setelah mendengarkan. Berdasarkan bunyibunyiyang didengar itu, kemudian manusia belajar untuk mengucapkan dan akhirnya terampil berbicara.

Puji Santosa, dkk (dalam Sutino 2011:16) mengemukakan bahwa tujuan keterampilan berbicara di SD adalah melatih siswa dapat berbicara dalam berbahasa dengan baik dan benar. Untuk mencapai tujuan pembelajaran tersebut, guru dapat menggunakan bahan pembelajaran membaca atau menulis dan kosa kata sebagai bahan pembalajaran berbicara. Misalnya, menceritakan pengalaman yang mengesankan, menceritakan kembali cerita yang pernah dibaca dan didengar, mengungkapkan pengalaman pribadi, bermain peran (role playing), dan berpidato. Pengamatan guru terhadap berbicara siswa dapat direkam dengan menggunakan format yang telah dipersiapkan sebelumnya. Faktor-faktor yang diamati adalah lafal kata, intonasi kalimat, kosa kata, tata bahasa, kefasihan berbicara, dan pemahaman.

\section{METODE PENELITIAN}

Jenis penelitian ini adalah penelitian kuantitatif. Menurut Sugiyono (2018:8) peneitian kuantitatif dapat diartikan sebagai metode penelitian yang berlandaskan pada filsafat positivisme, digunakan untuk meneliti populasi atau sampel, pengumpulan data menggunakan instrument penelitian, analisis data yang bersifat kuantitatif/statistik, dengan tujuan untuk menguji hipotesis yang ditetapkan.
Subjek data pada penelitian pengembangan ini adalah siswa kelas III SD di gugus RA Kartini Kecamatan Jaken, Kabupaten Pati. Siswa di SDN Lundo dan Kebonturi sebagai kelas role playing sejumlah 20 siswa, siswa di SDN Mojoluhur dan Tegalarum sebagai kelas snowball throwing sejumlah 20 anak, siswa SDN Sidomukti dan Gendolo sebagai kelas control sejumlah 20 siswa. Teknik Pengumpulan data menggunakan angket, observasi dan dokumentasi. Validitas instrument observasi ketrampilan berbicara menggunakan uji validitas logis. Pengujian validitas dilakukan oleh ahli yaitu oleh kepala sekolah.

Pengujian nilai ketrampilan berbicara siswa menggunakan analisis deskriptif dan analisis inerensisal. Analisis inferensial menggunakan uji parametict uji t-test . Karna menggunakan Uji parametric uji t-test maka perlu dilakukan uji validitas dan uji homogenitas terlebih dahulu. Uji ini dilakukan apabila peneliti menggunakan analisis parametrik, sehingga perlu dilakukan pengujian terhadap asumsi-asumsinya seperti uji normalitas dan homogenitas (Riduwan 2015:119). Setelah data normal dan homogen, uji hipotesis menggunakan uji hipotesis menggunakan uji independent sample $t$-tes dengan SPSS versi 20

\section{HASIL DAN PEMBAHASAN}

Analisis dilakukan setelah guru melakukan eksperimen dan memperoleh data. Sebelum dilakukan uji hipotesis dilakukan uji normalitas dan homogenitas terlebih dahulu. Uji normalitas menggunakan aplikasi SPSS 20. Nilai signifikansinya dapat dilihat pada kolom Kolmogorov-smirnov. data uji normalitas ketrampilan akakhir berbicara siswa disajikan dalam table berikut:

Tabel 1. Hasil Uji Normalitas Nilai Ketrampilan Akhir Tests of Normality

\begin{tabular}{llrrrrrr}
\hline \multirow{2}{*}{ kelas } & \multicolumn{3}{c}{ Kolmogorov-Smirnov $^{\mathrm{a}}$} & \multicolumn{3}{c}{ Shapiro-Wilk } \\
& & Statistic & $\mathrm{df}$ & \multicolumn{1}{c}{ Sig. } & \multicolumn{1}{c}{ Statistic } & Df & \multicolumn{1}{l}{ Sig. } \\
\hline \multirow{3}{*}{ hasil } & kelas role playing & .172 & 20 & .125 & .896 & 20 & .034 \\
& kelas snowball & .163 & 20 & .168 & .957 & 20 & .485 \\
& kelas kontrol & .166 & 20 & .151 & .955 & 20 & .456 \\
\hline
\end{tabular}


Analisis data untuk uji homogenitas menggunakan SPSS versi 20 dengan menu Analyze $\rightarrow$ Compare Means $\rightarrow$ One Way Anova, kemudian memberi tandaceklist $(\sqrt{ })$ pada menu Options $\rightarrow$ Test of Homogeneity of variance. Berikut ini merupakan hasil uji homogenitas, yaitu:

Tabel 2. Hasil Uji Homogenitas Nilai Ketrampilan Akhir

Test of Homogeneity of Variances

\begin{tabular}{cccc}
\multicolumn{4}{c}{ Hasil } \\
\hline Levene Statistic & df1 & df2 & Sig. \\
\hline .025 & 2 & 57 & .975 \\
\hline
\end{tabular}

Guna menjawab permasalahan uji hipotesis dilakukan sebnayak tiga kali. pertama untuk menguji hipotesis pertama tabel 3 hasil uji independent sample t-test kelas role playing dan konvensional

Table 3. Uji Hipotesis Kelas Role Playing dan Konvensional

\begin{tabular}{|c|c|c|c|c|c|c|c|c|c|c|}
\hline \multicolumn{11}{|c|}{ Independent Samples Test } \\
\hline & & \multicolumn{2}{|c|}{$\begin{array}{l}\text { Levene's Test for Equality of } \\
\text { Variances }\end{array}$} & \multicolumn{7}{|c|}{ t-test for Equality of Means } \\
\hline & & $\mathrm{F}$ & Sig. & $t$ & df & Sig. (2-tailed) & $\begin{array}{c}\text { Mean } \\
\text { Difference }\end{array}$ & $\begin{array}{l}\text { Std. Error } \\
\text { Difference }\end{array}$ & \multicolumn{2}{|c|}{$\begin{array}{l}95 \% \text { Confidence Interval of the } \\
\text { Difference }\end{array}$} \\
\hline \multirow[t]{2}{*}{ hasil } & $\begin{array}{l}\text { Equal variances } \\
\text { assumed }\end{array}$ & .058 & .811 & 3.943 & 38 & .000 & 10.15000 & 2.57444 & 4.93831 & 15.36169 \\
\hline & $\begin{array}{l}\text { Equal variances not } \\
\text { assumed }\end{array}$ & & & 3.943 & 37.115 & .000 & 10.15000 & 2.57444 & 4.93423 & 15.36577 \\
\hline
\end{tabular}

Berdasarkan tabel 3 menunjukkan nilai signifikansi kelas yang menerapkan model pembelajaran role playing sebesar $0.000(0.000<$ $0.05)$. Nilai $t_{\text {tabel }}$ dengan df 38 yaitu 2.024. Nilai $t_{\text {hitung }}$ sebesar 3.943 , sedangkan nilai $t_{\text {tabel }} 2.024$ yaitu (3.943 > 2.024). Mengacu pada kriteria pengambilan keputusan, dapat disimpulkan $\mathrm{Ha}_{1}$ diterima atau penerapan model pembelajaran role playing lebih berpengaruh daripada model pembelajaran konvensional dalam memacu ketrampilaan berbicara anak.

Hasil uji hipotesis kedua menggunakan uji independent sample t-test. hasil uji pengaruh perbedaan antara kelas yang menggunakan model snowball throwing dan konvensional ditampilkan pada table berikut:

Table 4. hasil uji independent sample t-test kelas snowball throwing dan konvensional

\begin{tabular}{|c|c|c|c|c|c|c|c|c|c|c|}
\hline \multicolumn{11}{|c|}{ Independent Samples Test } \\
\hline & & \multicolumn{2}{|c|}{$\begin{array}{c}\text { Levene's Test for } \\
\text { Equality of } \\
\text { Variances }\end{array}$} & \multicolumn{7}{|c|}{ t-test for Equality of Means } \\
\hline & & \multirow[t]{2}{*}{$\mathrm{F}$} & \multirow[t]{2}{*}{ Sig. } & \multirow[t]{2}{*}{$\mathrm{T}$} & \multirow[t]{2}{*}{$\mathrm{df}$} & \multirow{2}{*}{$\begin{array}{l}\text { Sig. (2- } \\
\text { tailed) }\end{array}$} & \multirow{2}{*}{$\begin{array}{c}\text { Mean } \\
\text { Difference }\end{array}$} & \multirow{2}{*}{$\begin{array}{l}\text { Std. Error } \\
\text { Difference }\end{array}$} & \multicolumn{2}{|c|}{$95 \%$ Confidence Interval of the Difference } \\
\hline & & & & & & & & & Lower & Upper \\
\hline \multirow{2}{*}{ hasil } & Equal variances assumed & \multirow[t]{2}{*}{.167} & \multirow[t]{2}{*}{.685} & 3.370 & 38 & .002 & 9.90000 & 2.93769 & 3.95297 & 15.84703 \\
\hline & Equal variances not assumed & & & 3.370 & 37.735 & .002 & 9.90000 & 2.93769 & 3.95159 & 15.84841 \\
\hline
\end{tabular}

Berdasarkan tabel 4 menunjukkan nilai signifikansi kelas yang menerapkan model pembelajaran snowball throwing sebesar 0.02 $(0.02<0.05)$. Nilai $t_{\text {tabel }}$ dengan df 38 yaitu 2.024 .
Nilai $t_{\text {hitung }}$ sebesar 3.370 , sedangkan nilai $t_{\text {tabel }}$ 2.024 yaitu $(3.370>2.024)$ Mengacu pada kriteria pengambilan keputusan, dapat disimpulkan $\mathrm{Ha}_{2}$ diterima atau penerapan model pembelajaran 
snowball throwing lebih berpengaruh daripada model pembelajaran konvensional dalam memacu ketrampilaan berbicara anak.

Hasil uji hipotesis ketiga menggunakan uji independent sample t-test. hasil uji pengaruh perbedaan antara kelas yang menggunakan model role playing dan snowball throwing ditampilkan pada tabel berikut:

Table 5. Hasil Uji Independent Sample T-Test Kelas Role Playing Dan Snowball Throwing Independent Samples Test

\begin{tabular}{|c|c|c|c|c|c|c|c|c|c|}
\hline & \multicolumn{2}{|c|}{$\begin{array}{l}\text { Levene's Test } \\
\text { for Equality of } \\
\text { Variances }\end{array}$} & \multirow{3}{*}{$\mathrm{T}$} & \multirow{3}{*}{ df } & \multicolumn{3}{|c|}{ t-test for Equality of Means } & \\
\hline & & $\mathrm{F}$ & Sig. & & & \multirow[t]{2}{*}{$\begin{array}{l}\text { Sig. } \\
(2- \\
\text { tailed) }\end{array}$} & \multirow[t]{2}{*}{$\begin{array}{c}\text { Mean } \\
\text { Differen } \\
\text { ce }\end{array}$} & \multirow[t]{2}{*}{$\begin{array}{c}\text { Std. Error } \\
\text { Differenc } \\
\mathrm{e}\end{array}$} & $\begin{array}{c}95 \% \text { Confidence } \\
\text { Interval of the } \\
\text { Difference }\end{array}$ \\
\hline & & & & & & & & & $\begin{array}{c}\text { Lower Uppe } \\
\text { r }\end{array}$ \\
\hline \multirow{2}{*}{$\begin{array}{l}\text { has } \\
\text { il }\end{array}$} & $\begin{array}{l}\text { Equal variances } \\
\text { assumed }\end{array}$ & $\begin{array}{r}.00 \\
2\end{array}$ & .969 & $\begin{array}{r}2.49 \\
8\end{array}$ & 38 & .017 & 6.60000 & 2.64197 & $\begin{array}{rr}1.25161 & 11.9 \\
4839\end{array}$ \\
\hline & $\begin{array}{l}\text { Equal variances } \\
\text { not assumed }\end{array}$ & & & $\begin{array}{r}2.49 \\
8 \\
\end{array}$ & 37.342 & .017 & 6.60000 & 2.64197 & $\begin{array}{rr}1.24852 & 11.9 \\
5148 \\
\end{array}$ \\
\hline
\end{tabular}

Berdasarkan tabel 5 menunjukkan nilai signifikansi kelas yang menerapkan model pembelajaran role playing sebesar $0.017(0.017<$ $0.05)$. Nilai $t_{\text {tabel }}$ dengan df 38 yaitu 2.024. Nilai $\mathrm{t}_{\text {hitung }}$ sebesar 2.498 , sedangkan nilai $\mathrm{t}_{\text {tabel }} 2.024$ yaitu $(2.498>2.024)$. Mengacu pada kriteria pengambilan keputusan, dapat disimpulkan $\mathrm{Ha}_{3}$ diterima atau penerapan model pembelajaran role playing lebih berpengaruh daripada model pembelajaran snowball throwing dalam memacu ketrampilaan berbicara anak. Pada kolom mean difference bernilai positif, maka nilai ketrampilan kelas role playing lebih besar daripada kelas snowball throwing. Ini menunjukkan bahwa kelas role playing lebih besar pengaruhnya daripada kelas snowball throwing.

Berdasarkan analisis yang dilakukan peneliti, siswa lebih aktif berbicara pada pembelajaran role playing. Hal ini terlihat dari langkah-langkah pemebelajaran role playing dimana guru sdh memberikan materi kepada siswa untuk dipelajarai terlebih dahulu. Disini siswa dituntut untuk memahami dulu naskah yang akan mereka peragakan di kelas, jadi siswa bias mempersiapkan dengan maksimal.

Seperti yang diungkapkan oleh Djamarah (2002:101) menjelaskan keunggulan model role playing sebagai berikut: 1)Siswa melatih dirinya untuk melatih, memahami dan memngingat isi bahan yang akan didramakan sebagai pemain harus memahami, menghayati isi cerita secara keseluruhan, terutama untuk materi yang harus diperankannya. Dengan demikian, daya ingatan siswa harus tajam dan tahan lama, 2) Siswa akan terlatih untuk berinisiatif dan berkreatif. Pada waktu main drama para pemain ditunut untuk mengemukakan pendapatnya sesuai dengan waktu yang tersedia, 3) Bakat yang terdapat pada siswa dapat dipupuk sehingga dimungkinkan akan muncul atau tumbuh bibit seni drama dari sekolah. Jika seni drama mereka dibina dengan baik kemungkinan besar mereka akan menjadi pemain yang lebih baik kelak. 4) Kerja sama antar pemain dapat ditimbulkan dan dibina dengan sebaikbaiknya, 5) Siswa memperoleh kebiasaan untuk menerima dan membagi tanggung jawab dengan sesamanya, 6) Bahasa lisan siswa dapat dibina mejadi bahasa yang baik agar mudah dipahami orang lain. Jika bahasa Lisan siswa baik, maka ketrampilan berbicara siswa juga mulai terasah menjadi lebih baik juga

Sedangkan keunggulan model pembelajaran snowball throwing menurut Huda (2014:226) sebagai berikut melatih kesiapan siswa, 
saling memberikan pengetahuan, terciptanya suasana belajar yang komunikatif. Pada pembelajaran snowball throwing dilakukan spontanitas saat pembelajaran. Sehingga siswa yang biasa menjawab dia akan lebih dominan sedangkan siswa yang belum belum menguasai materi akan cenderung diam. Hal ini yang menyebabkan pembelajaran menggunakan model snowball throwing cenderung lebih rendah dalam meningkatkan ketrampilan berbicara siswa.

\section{SIMPULAN DAN REKOMENDASI}

Penelitian ini dapat disimpulkan bahwa antara model pembelajaran role playing dan snowball throwing merupakan pembelajaran yang sudah mampu meningkatkan ketrampilan berbicara siswa dalam pelajaran bahasa Indonesia. Akan tetapi model pembelajaran yang paling berpengaruh terhadap ketrampilan berbicara siswa adalah model pembelajaran role playing. Pengujian hipotesis pertama tentang pengaruh kelas yang model pembelajaran role playing dengan kelas yang menggunakan pembelajaran konvensional. Hasilnya menunjukkan nilai signifikansi ketrampilan berbicara Bahasa Indonesia sebesar $0.000(0.000<0.05)$. Nilai thitung sebesar 3.943, sedangkan nilai tabel 2.024 yaitu (3.943 > 2.024). Mengacu pada ketentuan pengambilan keputusan uji hipotesis, maka $\mathrm{Ha}_{1}$ diterima. Dengan demikian, dapat disimpulkan bahwa model pembelajaran role playing berpengaruh daripada pembelajaran konvensional terhadap ketrampilan berbicara siswa SD kelas II di Gugus RA Kartini.

Pengujian hipotesis kedua tentang pengaruh kelas yang model pembelajaran snowball throwing dengan kelas yang menggunakan pembelajaran konvensional. Hasilnya menunjukkan nilai signifikansi ketrampilan berbicara Bahasa Indonesia sebesar $0.02(0.02<0.05)$. Nilai tabel dengan df 38 yaitu 2.024. Nilai thitung sebesar 3.370, sedangkan nilai $t_{\text {tabel }} 2.024$ yaitu $(3.370>2.024)$. Mengacu pada ketentuan pengambilan keputusan uji hipotesis, maka $\mathrm{Ha}_{2}$ diterima. Dengan demikian, dapat disimpulkan bahwa model pembelajaran snowball throwing berpengaruh daripada pembelajaran konvensional terhadap ketrampilan berbicara siswa SD kelas III di Gugus RA Kartini.

Pengujian hipotesis ketiga tentang pengaruh kelas yang model pembelajaran role playing dengan kelas yang menggunakan pembelajaran snowball throwing. Hasilnya menunjukkan nilai signifikansi ketrampilan berbicara Bahasa Indonesia sebesar sebesar 0.017 $(0.017<0.05)$. Nilai $t_{\text {tabel }}$ dengan df 38 yaitu 2.498 dan $t_{\text {hitung }} 2.024$, jadi nilai $t_{\text {hitung }}$ lebih besar dari $t_{\text {tabel }}$ (2.498>2.024). Mengacu pada ketentuan pengambilan keputusan uji hipotesis, maka $\mathrm{Ha}_{3}$ diterima. Dengan demikian, dapat disimpulkan bahwa model pembelajaran role playing berpengaruh daripada pembelajaran snowball throwing terhadap ketrampilan berbicara siswa SD kelas II di Gugus RA Kartini.

\section{DAFTAR PUSTAKA}

Ali, M. K. (2013). PenggunaanMetode Role Playing Berbantuan Media Audiovisual untuk Meningkatkan Keterampilan Berbicara Siswa Kelas IVB SDN Grisikdono 03 Semarang. Skripsi. Semarang: Fakultas Ilmu Pendidikan, UniversitasNegeri Semarang.

Amri, S. (2013). Pengembangandan Model Pembelajaran dalam Kurikulum 2013. Jakarta: Prestasi Pustaka.

Apsari, Y. (2018). Snowball Throwing in Teaching Grammar. IKIP Siliwangi, Cimahi, 10(1), 52-59

Arikunto. (2013). Prosedur Penelitian suatu Pendekatan Praktik. Jakarta: Rieka Cipta.

Baroroh, K. (2011). Upaya Meningkatkan NilaiNilai Karakter Peserta Didik Melalui Penerapan Metode Role Playing. Pendidikan Ekonomi FE UNY, 8(2), 149163.

Besral. (2010). Pengolahan dan Analisis Data. Jakarta: FKM UI. Online http://www.spssindonesia.com/2019/10/ download-ebook-spss-gratis.html.

Daryanto dan Raharjo, M. (2012). Model Pembelajaran Inovatif. Yogyakarta: Gavamedia.

Dharmawan, D. W, dkk. (2014). Pengaruh Model 
Pembelajaran Role Playing Terhadap Keterampilan Berbicara Bahasa Indonesia Siswa Kelas V. e-Journal MIMBAR PGSD Universitas Pendidikan Ganesha Jurusan PGSD, 2(1), 12-20.

Ginting, M. (2017). Snowball Throwing Learning Model Implementation in Order to Increase Student Civic Education Learning Outcomes. Journal of Arts, Science \& Commerce, 8, 120.

Hamalik, O. (2010). Proses BelajarMengajar. Jakarta: PT Bumi Aksara.

Hamdani. (2011). Strategi Belajar Mengajar. Bandung: Pustaka Setia.

Haryani, dkk. (2013). Penerapan Model Pembelajaran Kooperatif Tipe Snowball Throwing dapat Meningkatkan Hasil Belajar IPA Tentang Struktur Bumi Pada Siswa Kelas V SDN Ngadiroyo Tahun Ajaran 2012/2013. PGSD FKIP Universitas Sebelas Maret.

Huda, M. (2013). Model-model Pengajaran dan Pembelajaran. Yogyakarta: Pustaka Pelajar.

Lyne, S. (2018). Role-playing and Simulation in Education Conference 2018. International Journal of Role-Playing .Halaman 1-9.

Mayasari, N. (2014). Peningkatan Keterampilan Berbicara pada Mata Kuliah Belajar dan Pembelajaran dengan Metode Debat Plus dalam Proses Pembelajaran Matematika pada Mahasiswa Tingkat 2 Semester III di IKIP PGRI Bojonegoro Tahun Pelajaran 2013/ 2014. MagistraNo. 88 Th. XXVI Juni 2014.ISSN 0215-9511.

Mulyasa. (2013). Pengembangan dan Implementasi Pengembangan Kurikulum. Rosdakarya: Bandung.

Murtono. (2017). Model-Model Pembelajaran Inovatif (Student Center Learning). Ponorogo: Wade group.

Putra dan Agus. (2017). The Implementation of Role Playing Learning Model to Increase Student Learning Activities and Outcomes.73-81

Putri, Y. E., dan Chatri, M. (2019). The Effects of
Snowball Throwing (ST) Model Aided by Activity Sheets with Nuances of Problem Solving on Student Skills. International Journal of Progressive Sciences and Technologies (IJPSAT), 15, 191-194

Rojas, M. A., dan Villafuerte, J. (2018). The Influence of Implementing Role-play as an Educational Technique on EFL Speaking Development. Theory and Practice in Language Studie, 8, 726-732.

Sari, R. K. (2020). Efektivitas Penggunaan Model Pembelajaran Role Playing terhadap Ketrampilan Berbicara Pada Bahasa Indonesia Tingkat SD. Jurnal Pendidikan Dan Konseling UKSW, 1(2), 69-76.

Sitepu, M. S. (2015). Pengaruh Penggunaan Metode Pembelajaran Role Playing Terhadap Prestasi Belajar IPS Siswa Kelas IV Sekolah Dasar di Yogyakarta. Jurnal Ilmiah Inkoma, 26(1).

Stephane. (2016). The Transformative Potential of Role-Playing Games: From Play Skills to Human Skills.

Sugiyono. (2009). Metode Penelitian Kualitatif. Bandung: Alfabeta.

Sunarsih, S. (2012). Pembelajaran Keterampilan Berbicara Model Kooperatif Teknik Mencari Pasangandan Teknik Kancing Gemerincing pada Siswa Introver dan Ekstrover di SMP. Kampus UNNES Bendar Ngisor Semarang 50233, ISSN 2301-6744.

Suryani. (2015) . The Effectiveness of Role Play in Teaching Speaking. Volume 3/II. STKIP Siliwangi Bandung. Halaman 106-109

Sutino. (2011). Peningkatan Keterampilan Berbicara Dengan Menggunakan Motode Role Playing Pada Siswa Kelas $V$ SDN Pandak 1 Sidoharjo Sragen Tahun Ajaran 2010/2011. Skripsi. Surakarta: Fakultas Keguruan dan Ilmu Pendidikan, Universitas Sebelas Maret Surakarta.

Woodley, X. M. (2016). Womanism and Snowball Sampling: Engaging Marginalized Populations in Holistic Research. New 
Jurnal PAJAR (Pendidikan dan Pengajaran)

Volume 5 Nomor 5 September 2021 | ISSN Cetak : 2580 - 8435 | ISSN Online : 2614 - 1337

DOI : http://dx.doi.org/10.33578/pjr.v5i5.8164

Mexico State University - Main Campus.

Volume: 21. Halaman 321-329. 